\title{
TWO IMAGES OF SHAKESPEARE IN ANTHONY BURGESS'S NOVEL “NOTHING LIKE THE SUN" AND IN JURIJ DOMBROVSKIJ'S STORIES ${ }^{1}$
}

\author{
Nina Bochkareva \\ Perm State National Research University \\ Bukireva 15, Perm, Russia \\ Telephone: +79617552567 \\ E-mail: nsbochk@mail.ru \\ Olga Averkieva \\ Perm Film Studio "Novij Kurs" \\ Petropavlovskaja 121, Perm, Russia \\ Telephone: +79091060607 \\ E-mail: ole-ole1990@mail.ru
}

Received on 2 July, 2013; accepted on 2 January, 2014

doi:10.13165/SMS-14-6-1-04

\begin{abstract}
The purpose of the article is to compare images of Shakespeare in the novel "Nothing like the Sun. A Story of Shakespeare's Love Life" (1964) by the English writer Anthony Burgess and in the stories "The Dark Lady", "The Second Quality Bed" and "The Royal Rescript" (1969) by the Russian writer Jurij Dombrovskij. Distinctions of the images are explained, first of all, by the different literary tradition and poetics of realism and modernism accordingly. Similarities speak of the commonality of the tendencies in the European historical and literary process of the 20th century, and also
\end{abstract}

1 The article has been written with RSSF suggestion (№ 12-34-01012a1, Ekphrastic Genres in Classical and Contemporary Literature). 
of the creative biography of writers, their aversion of totalitarianism and aspiration to create an image of a free person. The fundamental complexity is to create the image of the historic figure in general and Shakespeare in particular. It is as though shrouded by the foggy veil through which we can rather see the features of Burgess and Dombrovskij themselves than of the Stratford playwright that remains a riddle for readers.

Keywords: comparative study, image, genre, Shakespeare, English and Russian literature, Anthony Burgess, Jurij Dombrovskij.

\section{Introduction}

The purpose of the article is to compare images of Shakespeare in the novel Nothing like the Sun. A Story of Shakespeare's Love Life (1964) by the English writer Anthony Burgess and in the stories The Dark Lady, The Second Quality Bed and The Royal Rescript (1969) by the Russian writer Jurij Dombrovskij. The choice of the material for the research is motivated, first of all, by the time of creation of the works (1960s) and their thematic commonality: the title of Burgess's novel speaks for itself and a theme of Dombrovskij's stories is called as "Shakespeare's love story" The chosen texts remain in the periphery of the writers' works, outshined by more significant and famous novels. The only mentioning of the texts in one context states their absolute incomparability: "Shakespeare in Dombrovskij's texts is a sick person. Many biographers tend to think that the playwright suffered from some illness that forced him leave the theatre. We do not know what illness it was. At Dombrovskij's will, it was asthma. But there's nothing pathological in sick Shakespeare. I emphasize it to make a distinction between Dombrovskij's short stories and the novel by the modern English writer Anthony Burgess Nothing Like the Sun"3.

The belonging of the writers to different national cultures determines a choice of methodology of comparative-historical studying of literatures. An important task of the system analysis of the history of the world literature is a comparison of literary schools and genres. Considering these aspects, the authors of this article shall focus on the category of the image, or artistic image ${ }^{4}$. Comparing the images of Shakespeare by Anthony Burgess (1917-1993) and Jurij Dombrovskij (1909-1978), the authors of this article are interested, first of all, in the uniqueness of the author's creativity, originality of the writers' artistic decisions considering the commonality of their "starting points".

2 Dombrovskij, Yu. .Proza. Stati. Pisma. 1960-e gody/Vstupitelnaja statja i publikacija Grigorija Anisimova i Mihaila Emceva [Prose. Articles. Letters.1960s. Introduction and publication by Grigorij Anisimov and Mihail Emcev]. Nashe nasledie [Our heritage]. Moskva. 1991, 2. p. 98. Anikst, A. Novely o Shekspire [Stories on Shakespeare]. Novyj Mir [New World]. Moskva. 1971, 4. p. 254.

4 Gej, N. Khudozhestvenij obraz kak kategorija poehtiki [Artistic Image as a Poetics Category]. Kontekst-1982 [Context - 1982]. Moskva: Nauka, 1983, p. 68.

5 Brojtman,S. Istoricheskaja poehtika [Historical Poetics]. Moskva.Russian State University of Humanities. 2001, p. 256-259. 


\section{Myth or Biography?}

The mentioning of both writers in the Russian reference sources can be found in the additional volume of The Brief Literary Encyclopedia (Vol. 9, 1978). It is remarkable that the works the authors of the article are to analyze were included in the encyclopedic brief reviews, and the characteristic of their heroes and the author's position were opposite: "Burgess moves along the line of the antihero's searches in the mockingly exposing Shakespeare's 'counterbiography' Nothing Like the Sun"; "The tragic attitude and destiny of the artist are revealed by Dombrovskij in the book The Dark Lady. Three Short Stories about Shakespeare"7. Now Burgess (his most known novel is The Clockwork Orange) is viewed as the successor of George Orwell's traditions: “These writers have the accusation of totalitarianism and interest to the problem of the "new language of the future" in common". Dombrovskij's central work - the intellectual novel The Faculty of Useless Knowledge - has reflected the writer's long-term experience of opposition “to a meat grinder of totalitarian violence, unequal opposition from which he came out the winner, at least because he remained alive and has managed to conceive the historical tragedy he went through" 9 . Thus, Burgess and Dombrovskij share hatred for totalitarianism and the consecutive statement of a personal freedom. The name of reviews of the writers' works is remarkable in this sense: "Anthony Burgess: the Price of Freedom"10 and "The Taste of Freedom: To Jurij Dombrovskij's 25th Anniversary"11.

Besides that, Burgess's and Dombrovskij's prose styles share common features of the intellectual poetics. Its sources, in the authors' opinion, are in their huge erudition as critics and translators. The two writers are "keepers" and defenders of the national and world literatures and cultures, comprehending experience of antiquity and the Middle Ages, the East and the West. Both writers also address the figure of Christ - Burgess in the Man of Nazareth and Dombrovskij in The Faculty of Useless Knowledge. Burgess was a professional musician and scriptwriter;

6 Muravjev V. Berdzhes [Burgess]. Kratkaja literaturnaja ehnciklopedija [Short Literary Encyclopedia]. V. 9, 1978, p. 121.

7 Podolskaja I. Dombrovskij [Dombrovskij]. Kratkaja literaturnaja ehnciklopedija [Short Literary Encyclopedia]. V. 9, 1978, p. 285.

8 Mihalskaja, N. Istorija anglijskoj literatury [History of English literature]. Moskva: Akademija. 2006, p. 417.

9 Leiderman, N. Lipoveckij, M. Sovremenaja ruskaja literatura. 1950-1990-e gody. [Contemporary Russian Literature. 19950-1990.] In 2 volumes. Moskva: Akademija, 2006. Volume 2, 1968-1990, p.204

10 Doroshevich A. Ehntoni Berdzhes: Cena svobody [Anthony Burgess: The Price of Freedom] Inostranaja literatura [Foreign literature]. Moskva. 1991 12, p. 229-233.

11 Ermolina, A. Vkus svobody: nad stranicami romana. K 25-letiju Jurija Dombrovskogo [The Taste of Freedom: Out of the Pages of the Novel. On the 25th Birthday of Jurij Dombrovskij]. Kontinent [The Continent]. 2003.2, p. 413-422. 
Dombrovskij worked at the theatre, wrote stories about architects, sculptors and painters of Kazakhstan ${ }^{12}$. Their interest to Shakespeare cannot be called incidental. Burgess wrote several lectures and articles about Shakespeare, the script for the Hollywood about his life, the biography Shakespeare (1970) and novels MF (1971), Enderby's Dark Lady (1984), Dead Man in Deptford (1993), "the characters and plot intrigue of which [the novels] are directly connected with Elizabethan epoch and its most important protagonist, the great English bard"13. Having first seen The Merchant of Venice on stage of the summer dacha theatre near Moscow (1915-1916), Dombrovskij "has many times re-read all Shakespeare's things in the original" and "almost all the main works written about Shakespeare in five languages" ${ }^{4}$. In AlmaAta, he read a course of lectures on Shakespeare for students of the theatre institute: "He devoted eleven lectures to Hamlet and at that he did not use any records or abstracts"15. Addressing the dead friend, Jurij Davidov writes: "Shakespearian Space was a lifelong destiny for you"16. Indeed, Shakespearian reminiscences are found both in his novel The Keeper of Antiquities and in the stories Lady Macbeth, The Hand, Leg, Little Cucumber... and The Sculptor Etkind's Masks. Dombrovskij wrote two forewords to the English and Italian editions of the stories about Shakespeare and later the article Renlendbaconsouthhemptonshakespeare.

The critic Jakov Gordin maintains that "Dombrovskij"s book is not perceived as the book of biographic stories at all. It is perceived as one of the myth variants $\langle\ldots\rangle$ the writer undertakes to prove: the myth cannot be less convincing, than documentary prose. But Dombrovskij is honest with the reader. He proves exactly the persuasiveness of the myth, instead of its historical validity. Dombrovskij's thin, clever and severe prose mystifies nobody"17. Dombrovskij himself, in the article mentioned above, disagrees with Gordin: the heroes of a literary myth "are possible only in that phantasmagoric world which was constructed for them by authors. Shakespeare lives in the world of people. He is a very strong and good contemporary of his epoch $\langle\ldots>$ What is required is the creative comprehension, even more - a personal union with the hero, display of his character by all experience of your life $\langle\ldots>$ if I write about Shakespeare it should be a story about my Shakespeare $<\ldots>$ My story is authentic as

12 Dombrovskij, Yu.Vajatel masok Itkind [Mask maker Itkind]. Fakel: raskazy [A Torch: stories]. Alma-Aty: Zhasushy. 1974. p. 44-59.

13 Gorbacheva, M. Dva Shekspira Ehntoni Berdzhesa [Two Shakespeares of Anthony Burgess]. Inostranaja literatura.[Foreign literature]. 2002. 8. p. 268-269.

14 Dombrovskij, Yu., supra note 2, p. 100.

15 Ibid., p. 98.

16 Dombrovskij, Yu. Smuglaja ledi: Roman, povest, novely [Dark Lady: a Novel, a Long Story, Short Stories. Vmesto predislovija Jurija Davydova [In place of Jurij Davydov's preface]. Moskva: Sovetskij pisatel, 1985. p. 5.

17 Gordin, Ja. Vozmozhen li roman o pisateli? [Is a Novel About a Writer Possible?] Voprosy literatury [Literary Issues]. 1975, 9. p.195-196. 
long as the story about the man about whose life we, unfortunately, know less that we would like to know, can be authentic $\langle\ldots\rangle$ it is not up to me to explain the difference between the proved guess (hypothesis) and a myth $\langle\ldots\rangle$ each work about a person that lived once, to some extent will be a biographic hypothesis"18.

Dombrovskij "chose only three moments from Shakespeare's life, but he presented them so that the playwright and people that surround him refer to the previous events and consequently the whole Shakespeare's life is reflected in these three short stories"19. Thus, Dombrovskij's cycle of short stories approximates to the novel. The history of creation of the story The Dark Lady is a curious one. Valentin Nepomnjashchy in the foreword with a symbolical name Homo Liber recollected a conversation with Dombrovskij about the lost manuscript of his book in seven stories on a theme "The Poet and His Muse": "one of parts was about Pushkin $\langle\ldots\rangle$ the manuscript was gone without a trace, The Dark Lady miraculously remained"20. Lev Varshavsky recollected the following: "I was lucky to observe within several years with what titanic work the book about Shakespeare "The Dark lady" was created. Jurij Dombrovskij wrote, confined to bed by illness, I hardly had time to supply him with literature kindly given by Alma-Ata libraries or sent from Moscow and Leningrad. In this work, Dombrovskij has proved to be not only the gifted artist of a word, but also the laborious researcher, the historian"21.

\section{Epigraphs and Introductions}

Both works - the novel and the cycle of stories - start with epigraphs. However, these epigraphs are very different, and, in the authors' opinion, the authors pursue quite different purposes, opening their literary creations with epigraphs.

Dombrovskij uses two statements, which are opposed to his conception of the work and his thought about Shakespeare, stated in forewords and articles. That is "it is a testimonial from the opposite" traditional concept of authorship of Shakespearian texts: "Only a fool can think that the Stratford Shakespeare is the author of Hamlet and King Lear" (From an old book on Shakespeare). But the writer and biographer Dombrovskij, as well as Burgess, is just the supporter of this traditional point of view, i.e. "a fool". The second epigraph touches upon another troublesome for Shakespearian

18 Dombrovskij, Yu. Khranitel drevnostej: Roman, novely, ehse. Predislovije Valentina Nepomnjasshego [The Keeper of the Antiquities: A Novel, Short Stories, Essays. Introduction by Valentin Nepomnjasshij. Moskva: Izvestija. 1991, p. 119-122.

19 Anikst, A., supra note 3. p. 254.

20 Dombrovskij, Yu., supra note 18, p. 5.

21 Dombrovskij, Yu., supra note 2, p. 98.

22 Gordin, Ja., supra note 17, p. 196. 
biographers and writers in general theme of a myth: "According to the unanimous conclusion of scholars, Gulliver is nothing but a myth, a legend created by simple people, in view of its propensity to wonderful and unusual. Gulliver never existed, and the one who maintains the opposite, loses the rank of the scholar, is forever expelled from academy and is cursed in The Year-Book" (Leonid Andreev). This ironical passage emphasizes the problem of historical and art reliability of the character. So, the epigraphs to The Dark Lady are chosen by Dombrovskij according to the principle "by contradiction". They specify a problem which excites the author and bring attention to the question that he answers within his text. It is remarkable that in both citations neither internal experiences of the hero of the stories, nor his love sufferings, nor he as the person are mentioned at all. The epigraphs, more likely, tend to reflect the issues that relate to the author himself as a biographer and a writer.

The epigraph, being the opening of the famous 130th Shakespearian sonnet $M y$ Mistress' Eyes Are Nothing like the Sun, explains the name of Burgess's novel ${ }^{23}$. As an epigraph Burgess uses the four first lines of the 130th sonnet:

My mistress' eyes are nothing like the sun,

Coral is far more red than her lips' red,

If snow be white, why then her breasts are dun,

If hairs be wires, black wires grow on her head.

This epigraph directly concerns the feelings and emotions of the protagonist. Through the epigraph, the author defines the basic characters of the novel: Shakespeare and the Dark lady. Besides that, he determines the role of the Dark lady in Shakespeare's love life; in fact, her image pursues the hero since childhood and leads up to the deathbed. The novel opens with a phrase "it was all a matter of a goddess - dark, hidden, deadly, horribly desirable"; and "the tragic motive of the hero's constant searches for the black goddess [and the author insists that the Dark Lady really dark-skinned] goes through the novel" ${ }^{24}$.

In the authors' opinion, the name of the novel, in which the second half of the sonnet's first line is used ("Nothing like the sun"), can relate both to the Dark Lady, and to Shakespeare. The meaning of the name is connected with the "main tendency for the English literature of the second half of the 20th century to discredit the settled social, cultural and literary myths, reconstructing or rethinking them"25. It is remarkable that Anikst also pointed at "the general tendency to interpret Shakespeare's personality, affirmed in our century", with which Dombrovskij agrees in the stories: "Present biographers and authors of the fictionalized biographies aspire

23 The Russian version of the publishing house "Centrpoligraph" guided by commercial objectives substituted its name by the name of a popular film "Shakespeare in Love" (Great Britain, USA, 1998, director John Medden, one of the authors of the script - Tom Stoppard).

24 Gorbacheva, M., supra note 13, p. 270.

25 Ibid., p. 269. 
to destroy iconographic Shakespeare created by the Victorian biographers in the 19th century, who gave comeliness and stateliness to, in their opinion, the national hero"26.

But let's return to the epigraphs and draw a conclusion that Dombrovskij's epigraph concerns the author more and reflects his problems, and the epigraph in Burgess's novel directly expresses a private world of the protagonist. From the first lines, it can be seen that the Russian writer's approach to the creation of the biography is more detailed, objectified and scholarly, whereas the English writer takes a great interest in creativity of the "Great master" and becomes engrossed in it.

It is necessary to make a reservation at this point. In the second chapter of the first story The Dark Lady, Dombrovskij uses two more epigraphs, this time from Shakespeare's works: "That you were once unkind befriends me now, // And for that sorrow, which I then did feel, // Needs must I under my transgression bow, // Unless my nerves were brass or hammer'd steel" (120th sonnet, Samuil Marshak's translation) and "I found you as a morsel cold upon // Dead Caesar's trencher; nay, you were a fragment // Of Cneius Pompey's; besides what hotter hours, // Unregister'd in vulgar fame, you have // Luxuriously pick'd out: for, I am sure, // Though you can guess what temperance should be, // You know not what it is" (Antony and Cleopatra, Boris Pasternak's translation). The chapter, in which both epigraphs are used, is devoted to Shakespeare's night conversation with Pembroke. The feelings expressed in Shakespearian lines can belong to both heroes. Thus, in these epigraphs, Dombrovskij expressed Shakespeare's private world, but as though through a prism of another consciousness. This aspect will be discussed in more detail in connection with narration in the works.

The construction of Burgess's novel is strange in a modernist fashion and is obscure at first. Everything is mixed here: the monologues of the protagonist, dialogues of minor characters, reasonings of the author, though the chronological sequence of events is observed by the writer with a surprising accuracy. The years are specified instead of the names of the parts of the novel: 157?-1587 and 1592-1599; the 6 th chapter of the second part represents a diary dated from February 4th till June 26th (the year is not specified).

Burgess, the lover of surprises and unexpected turns, creates a nonconventional, even shocking, composition frame to narrate about Shakespeare. The novel begins with the author's introduction: 
Mr Burgess's

Farewell lecture to his

special students (Misses Alabaster,

Ang Poh Gaik, Bacchus, Brochocki, Ishak,

Kinipple, Shackles, Spottiswoode and Messrs

Ahmad bin Harun, Anguish, Balwant Singh, Lillington, Lympe, Raja Mokhtar, Prindable, Rosario, Spittal, Whitelegge etc) who complained that Shakespeare had nothing to give to the East. (Thanks for the farewell gift of three bottles of samsu. I will take a swig now. Delicious.) The text being the acrostical significance of the following lines: '... My love is as a fever-

Feeding on that which doth preserve the ill, The uncertain sickly appetite to please. My reason, the physician to my love, Angry that his prescriptions are not kept, Hath left me ...'

The graphic form of the introduction gives associations with a bottle or a keg. From this introduction, it can be understood that the novel is written in the form of Mr. Burgess's farewell lecture to his special students, who complained that Shakespeare had nothing to give to the East. In the first brackets, the names of these students are listed, among which there is the god of wine (Bacchus), as well as polysemantic or absurd, Jewish (Ishak), Arabian (Ahmad bin Harun), English (Lillington) and other names are listed, as well.

In the second brackets, the first Mr. Burgess's "libation" is described: "Thanks for the farewell gift of three bottles of samsu. I will take a swig now. Delicious". $M r$. Burgess appears not only on the first page of the novel. Plentiful libations met with enthusiastic and incoherent exclamations are in the beginning of VI chapter of the first part (157?-1587), II and VII chapters of the second part (1592-1599) and, certainly, in the epilogue.

The introduction comes to an end with an acrostic from the 147th sonnet. For some reason, it starts with dots, though the first line is the very beginning of a sonnet, and dots should be put instead of a dash. To understand the text better, let's quote the sonnet entirely, emphasizing the lines used by Burgess:

My love is as a fever, longing still

For that which longer nurseth the disease,

Feeding on that which doth preserve the ill,

The uncertain sickly appetite to please.

My reason, the physician to my love,

Angry that his prescriptions are not kept, 
Hath left me, and I desperate now approve

Desire is death, which physic did except.

Past cure I am, now reason is past care,

And frantic-mad with evermore unrest;

My thoughts and my discourse as madmen's are,

At random from the truth vainly express'd;

For I have sworn thee fair and thought thee bright,

Who art as black as hell, as dark as night.

The last lines of the sonnet directly characterize the Dark lady (Shakespeare's beloved), but Burgess chooses the words, in which love of the poet is described as fever for which the treatment by reason was useless. These motives appear important in the poetics of the novel.

And now we shall return to the introduction to decipher the name hidden in the acrostic. We shall arrange the first letters formed by Burgess's lines in the following order: $1,5,3,2,4,5,6$. It turns out as FATIMAH.

Feeding on that which doth preserve the

ill,

The uncertain sickly appetite to please.

My reason, the physician to my love,

Angry that his prescriptions are not kept,

Hath left me...

During the biggest part of the narration, the Dark lady remains anonymous: the author uses the pronoun she. In the third chapter of the epilogue when the goddess comes to Shakespeare, he (or Burgess himself) recollects the black beloved, naming her with one letter $F$. And only in the last chapter of the epilogue, where Shakespeare's consciousness absolutely merges with the consciousness of the lecturer Mr. Burgess, he blames love for everything, for the first time naming her with the full name: "Love, love, and it is always love. Not wisely but too. Fatimah. I will distribute copies of that sonnet after the lecture"27. So, the end of the novel brings us back to its beginning. A solution to acrostic (the lines from Shakespeare's 147th sonnet) is the name Fatimah, and love, the Dark lady, Fatimah is the reason of all reasons. Thus, in the introduction, as well as in the epigraph, Shakespeare's sonnets devoted to the Dark lady are used, i.e. the feelings of the poet are in the center of the novel from its very beginning.

\section{Plot, Structure, Narration}

Jurij Dombrovskij chooses three episodes from Shakespeare's biography and creates three stories: The Dark Lady, The Second Quality Bed and The Royal Rescript. 
In the first story, Shakespeare is seen on the peak of his creative life. In the second one, he is an old actor and the playwright who lost the theatre, whereas the third story is about the head of the family, a good friend, the great poet on the deathbed. Each story is broken into chapters, but stories are not equivalent in size. Dombrovskij and his critics often name the whole cycle The Dark Lady, though that is the name only of the first biggest story that is divided into chapters "Theatre", "The Night Conversation", "The Earl of Essex" and "The Dark Lady of Sonnets".

The name of the first story and its fourth chapter emphasize that the peak of Shakespeare's creative life was connected with the love for the Dark lady. Here, the Russian stories and the English novel are closely connected, but at the same time they also differ. Burgess's work covers the period of the playwright's life up to 1599, before Hamlet was written, i.e. the first half of his creative way. In The Dark Lady, Dombrovskij addresses events, which directly preceded Hamlet's creation, and in two other stories - to the second half of Shakespeare's life.

Therefore, the significance allocated to the Dark lady is different in the works. If in Burgess's novel she is in the center of the novel and experiences of the protagonist, in Dombrovskij's work the heroine of the sonnets remains in the past and becomes, according to the author, "the casual woman".

Partly it is explained by the fact that Dombrovskij shares Bernard Show's opinion that the main heroine of Shakespearian sonnets was Mary Fitton, the maid of honour of the Queen Elizabeth. In the developed preface to The Dark Lady of Sonnets, Show speaks about the history of creation of this concept, naming Thomas Tyler its author. Show also mentions "the later suggestion of Mr. Acheson that the Dark Lady, far from being a maid of honor, kept a tavern in Oxford and was the mother of Davenant the poet". The latter was also Shakespeare's historical beloved and she is the heroine of Dombrovskij's second story The Second Quality Bed, whereas Mary Fitton is the heroine of the first story The Dark Lady.

Unlike Dombrovskij, Burgess thinks out the "goddess", gives her an exotic eastern name, rather dark skin, absolutely original destiny and, most importantly, a lifelong love of the "Great master Shakespeare". Contrary to Burgess, Dombrovskij makes each story connected with a different women, and therefore, with different feelings and emotions. In The Dark Lady, Shakespeare's heart is still young, and his love is passionate, ardent and mad. In The Second Quality Bed, the poet grows old, and so his feelings grow quiet and gentle. In The Royal Rescripte, there is no much space left in Shakespeare's life for love - he is sick and prepares for death, and the only woman who remains with him up to the end is a quarrelsome wife: "And to love is, probably, not the most important thing in this life. And it turns out, that $\langle\ldots\rangle$ I come to my old malicious wife ..."28

Thus, the life of the "Great master Shakespeare" in Dombrovskij's stories is as precisely built as the composition of the stories, and the destiny of the poet in 
the Burgess's novel is as irrational, mystical and mysterious as the composition of his work. At the same time, the English biographer makes the Stratford playwright experiences the same various palettes of feelings to one woman, as the Russian writer does with three different representatives of the fair sex.

Even though Shakespeare is a protagonist in Dombrovskij's story The Dark Lady, the writer does not show a private world of the Stratford playwright. Only sporadically the reader comes across the poet's reflections: "But Essex, Essex, here what tormented him! Yes! Now, perhaps, there's nothing you can do. The queen needs his head"29. These reflections, however, are not connected directly with Shakespeare's love life. It turns out that love interests the poet less than political intrigues and destiny of his patron.

The love scene in The Dark Lady is basically written from Mary Fitton's perception: "All of a sudden he quickly and resolutely entered into a room! $<\ldots>$ How direct he was, when looked at her! $\langle\ldots\rangle$ And he perfectly understood it, that here at this moment she needed these rough and rigid hands more than anything!"30 In this scene, the English poet becomes an ideal of the man, in his mistress's opinion, but Shakespeare himself remains a riddle. And only before he left the reader gets a glimpse of his carefully hidden feelings and experiences: "He felt himself a true traitor because, already going along the street, he knew it perfectly well that he would turn back and would not take any part in the rebellion..." ${ }^{31}$ And again, the poet's reflections are connected not so much with the Dark lady, but with his civic position.

Dombrovskij takes the position of the impersonal storyteller, but nevertheless, he often uses free indirect speech and internal monologue. The first story is devoted to Mary Fitton; therefore, it is from her perspective that the reader receives almost all the basic information on Shakespeare. It is interesting that Dombrovskij excludes the chapter "Queen", in which the English bard does not appear at all, and Mary Fitton talks to the queen about Essex, Bacon and Pembroke and only reads Shakespeare's sonnet $^{32}$. There is also another playwright and the actor that evaluates Shakespeare: "The Fox! - thought Chettle. - See, how he is showing off. You had better played so on the stage!" 33 The author conducts narration in such a way that by the end of the story the reader has a many-sided representation of Shakespeare through a prism of many characters. It is, in the authors' opinion, the main artistic device of the Russian Shakespeare's biographer.

If in the first story Dombrovskij assesses Shakespeare through the eyes of his mistress, friends and colleagues, the second story tells us about him through his family members and the Stratford pastor, who calls the known playwright and the

29 Dombrovskij, Yu., supra note 18, p. 156.

30 Ibid., p. 164.

31 Домбровский, Юрий. Хранитель древностей: Роман, новеллы, эссе. Dombrovskij, Yu. Supra note 18, p. 165.

32 Dombrovskij, Yu., supra note 2, p.104.

33 Dombrovskij, Yu., supra note 18, p.158. 
actor a "London dandy that tries to look younger, in a raincoat and with a nobiliary sword on one side"34. In the story The Second Quality Bed, Dombrovskij uses a long Shakespeare's internal monologue, where his personal emotions, feelings, attachments are opened up. The external estimation of the protagonist sharply contrasts with his inner world. In this story, the Stratford poet is not an ideal of the man, but a simple person with fears, illnesses and "last and strongest love".

The third story is narrated through the prism of Mr. Symons Grow's view, the young assistant to the doctor Hall who becomes the witness of Shakespeare's last days. Why does Dombrovskij show the death of his hero through the prism of another person when he is surrounded by relatives and close friends? It seems that the third story appears the most objective and realistic. Here, the author proves that his work has nothing in common with a myth. Therefore, the story The Royal Rescript comes to an end with an epilogue in which citations from Shakespeare's Will are given, together with the excerpts from the Shakespearian scholars' books of the 18th (Rowe), 19th (Brandes) and 20th (Morozov) centuries; and from himself the author adds: "Well! Whatever they say!"35

It is enough to compare Dombrovskij's extremely laconic and objectified epilogue to the epilogue of Burgess's novel, where the hero's incoherent ideas merge with the author's infinite monologue to understand the difference between the works of the Russian and English authors. If Dombrovskij's narrative style and the image of the protagonist vary depending on the characters' viewpoints, in Burgess's novel everything depends on the hero's ideas and experiences or the storyteller as their voices merge: "Ah, we are all damned. There is truly evil lying coiled in good; did not God create Lucifer and foreknow the colour and heat of the light he was to bear? So desire is part of love, and desire unacted is evil, therefore enact that desire - away, hid, indifferent, secret - and cleanse love as a well is cleansed"36. Whose words are these? Do they belong to the lewd Adam (tough demanding Adam) that lives in William's soul? Or to Mr. Burgess who whispers the hero how to satisfy desire and to keep the visibility of virtue? It makes the reader doubt the objectivity of Shakespeare's literary biography. Using this manner of narration, Burgess, first of all, expresses himself, his own creativity, connecting the $I$ with a private world of the protagonist. It is allowed to a novelist, but not to a biographer.

Probably for this reason Shakespeare in Burgess's novel is a truly main character. The novel describes the character's feelings, experiences, emotions; his inner contradictions are presented as different voices: “... he wondered whether, with death always lurking in alleyways, tainted meat, sour ale, death a very contending twin of life, those great cries about honour and rank and treachery were more than the bawlings of a fretful child in a cradle. Honour is a mere scutcheon. Who hath it? $\mathrm{He}$ that died o'Wednesday. A mere scutcheon? A mere scutcheon?" ${ }^{37}$ The author turns 
the poet's soul inside out. On the contrary, in the biography of Shakespeare, which Burgess wrote after the novel, the figure of the poet is covered by his environment.

There are other characters in Burgess's novel as well, but they are not so important as in Dombrovskij's stories. They are mostly actors, family members and Shakespeare's friends. For example, in both authors' works, there are an actor Burbage and a doctor Hall; Pembroke in Dombrovskij's story is similar to Harry in Burgess's novel. Many events are happening in Burgess's novel that do not relate to Shakespeare's life directly, but they are perceived as in a fog. The most important is how the hero's consciousness is reflected and how he is preoccupied with his Goddess. Here is how he describes Fatimah: "Lying on, in, under her, I pore with squinting eyes on a mole on that browngold rivercolour riverripple skin with its smell of sun, or else a tiny unsqueezed comedo by the flat and splaying nose"38.

So, if in Dombrovskij's stories narration is impersonal, and Shakespeare is shown basically through a prism of other characters, in Burgess's novel he is represented from the hero's viewpoint, and "the lecturer Mr. Burgess" merges with the hero's perspective. In the epilogue, the fever and delirium of the drunk lecturer and the sick hero turn to a stream of consciousness that even hints at the author's and poet's possible blood connection: "The West is eveningland, the East morningland. He sent his blood out there. I am of his blood. The male line died in the West. It was right it should continue in the East. Summon no one. I shall be all right. One short sleep past"39.

\section{Conclusion}

In conclusion, the following points can be summarized. Written almost simultaneously, Anthony Burgess's novel Nothing like the Sun. A Story of Shakespeare's Love Life (1964) and Jurij Dombrovskij's story cycle "The Dark Lady," "The Second Quality Bed" and "The Royal Rescript" (1968) reflect the common tendency of the 20th century literature to refuse the idealization of Shakespeare and challenge stereotypes that surround the poet. Both writers address the theme of love in their works, therefore, the Dark lady, the heroine of Shakespeare's sonnets, comes to the focus of attention in their works. The central themes of illness, death and creativity, explored by the authors, are also connected with her.

The Dark Lady designates the middle of Shakespeare's life and creative way, the boundary of the 15-16th centuries, years 1600-1601 when Hamlet was written. Burgess addresses to the first half of this period - the basic narration is dated 157?-1587 and 1592-1599, i.e. before Hamlet and other best tragedies were written. The poet's inner formation and maturing, which comes to an end with his illness, is in the center of Burgess's attention. Dombrovskij, on the contrary, begins the 
cycle with year 1600, when the Essex rebellion took place and Shakespeare wrote his most significant work. The two following stories of Dombrovskij's cycle are already devoted to 1612 and 1616, when Shakespeare lost the theatre and came back home, where he fell sick, grew old and died.

Dombrovskij borrows the name for the first story from B. Show's interlude Dark Lady of the Sonnets and makes the main heroine Mary Fitton, a maid of honour for the Queen Elizabeth. But Mary in Dombrovskij's story is not a unique love of Shakespeare's life, but a "casual woman" who is replaced by Jane in the second story, a tavern-keeper from Oxford and another historical candidate to the rank of the Dark lady. The main heroine of the third story is Anna - Shakespeare's lawful wife, to whom he returns to die.

Burgess offers quite an ingenious solution: he makes the Dark lady the true eastern beauty with a dark golden skin, a mysterious stranger, whose name Fatimah is ciphered in the acrostic from the 147th sonnet. In the original text, the name appears right at the end of the epilogue, and in the diary it is designated by the letter F. Dombrovskij makes Mary Fitton's first appearance in the text mysterious and enigmatic, as well - she changed clothes for a man's dress. The motive of changing dresses comes from Shakespeare's comedies The Twelfth Night, or What You Will and As You Like It. The reminiscences from these plays are also used in the Burgess's novel.

Creating the novel about the inner formation of the poet, Burgess shows Shakespeare from within; he employs the sonnets in the epigraph and the introduction, and in the basic narration he uses indirect and free indirect speech, internal monologues and even a diary. Moreover, in the author's frame shocking the reader, "Mr. Burgess" periodically supping samsu from three bottles presented by eastern students, appears to be so drunk by the epilogue that the characters' voices barely discernible from the storyteller's voice finally merge in the general stream of consciousness, and the lecturer thinks himself Shakespeare's descendant from the eastern bloodline. As a result, the image of the English bard appears extremely subjectified. Other heroes and events play a supporting role, fade into the background and become dissolved.

Dombrovskij, on the contrary, shows his hero through a prism of a set of other characters, their perception, estimation and behaviour in relation to Shakespeare and to each other. The author pays more attention to the environment than to the master himself in the stories. Trying to discredit the myth that Shakespeare from Stratford could not be the author of Hamlet and King Lear, designated in the epigraph, Dombrovskij objectifies the narration as much as possible. In the epilogue, he places excerpts from the original document Will and books of the famous Shakespearian scholars of the 18th, 19th and 20th centuries. However, he, as well as Burgess, uses sonnets and citations from Shakespeare's other works, free indirect speech, internal monologue and dialogue for the expression of the main character's feelings and ideas. Insisting on historical reliability, Dombrovskij maintains that he still shows his Shakespeare as everyone has one's own Pushkin, etc. 
Both authors create a tragical image of the actor, the playwright, the worker, the poet, the friend and the lover. Both authors also show the underside of the myth about "the comely and stately national hero" (Anikst), not hiding sinfulness both of the poet and the world he lived in. Burgess leads up a problem of good and evil, spirit and flesh to the point of absurdity, confirming that "literature is only the epiphenomenon of the flesh's activity". His Shakespeare is passionate and unrestrained, although he stays in constant internal reflection and introspection. Shakespeare in Dombrovskij's works is much calmer, more moderate; the author mostly focuses on the external conflict of the playwright with the society. Internal conflict is shown in fragmentation; the author emphasizes reticence, restraint and dignity of the character.

The theme of creativity in Burgess and Dombrovskij's works is closely connected with life, love and even with illness and death. In the Burgess's novel, the vision of the golden goddess that haunted the poet since childhood, although reminiscent of Fatimah, most importantly symbolizes creativity, a muse of inspiration and artistic search. Dombrovskij devotes only the first story to the theme of creative process because when Shakespeare came back home, he stopped writing. The destiny of his works, however, becomes the central theme of the second and third stories. The meaning of the Will varies from "the second quality bed" to the manuscripts of a doctor Hall and Shakespeare's works.

Distinctions in the contents and the form of the images created by the Russian and English writers are explained, first of all, by the literary tradition on which they lean, that is the poetics of realism and modernism accordingly. Similarities that were marked by the authors of the article speak of the commonality of the tendencies in the European historico-literary process of the 20th century, and also of the creative biography of writers, their aversion of totalitarianism and aspiration to create an image of a free person. However, it should be noticed that the fundamental complexity of creation of the image of the historic figure in general and Shakespeare in particular leads to that in the texts of both authors, despite the doubtless advantages of the works, the image of the protagonist is obscure. It is as though shrouded by the foggy veil, through which rather the features of Burgess and Dombrovskij themselves can be seen than of the Stratford playwright that remains a riddle for readers.

\section{References}

Anikst, A. Novely o Shekspire [Stories on Shakespeare]. Novyj Mir [New World]. Moskva. 1971, No.4.

Brojtman,S. Istoricheskaja poehtika [Historical Poetics]. Moskva. Russian State University of Humanities. 2001.

Burgess, A. Nothing Like the Sun: A Story of Shakespeare's Love-life. New York, 1964.
Dombrovskij, Yu. Proza. Stati. Pisma. 1960-e gody/Vstupitelnaja statja i publikacija Grigorija Anisimova i Mihaila Emceva [Prose. Articles. Letters.1960s. Introduction and publication by Grigorij Anisimov and Mihail Emcev]. Nashe nasledie [Our heritage]. Moskva. 1991, No. 2. 
Dombrovskij, Yu. Khranitel drevnostej: Roman, novely, ehse. Predislovije Valentina Nepomnjashhego [The Keeper of the Antiquities: A Novel, Short Stories, Essays. Introduction by Valentin Nepomjashhij]. Moskva: Izvestija, 1991.

Dombrovskij, Yu. Vajatel masok Itkind [Mask maker Itkind]. Fakel: raskazy [A Torch: stories]. Alma-Aty: Zhasushy, 1974.

Doroshevich A. Ehntoni Berdzhes: Cena svobody [Anthony Burgess: The Price of Freedom] Inostranaja literatura [Foreign literature]. Moskva.1991. No. 12.

Ermolina, A. Vkus svobody: Nad stranicami romana. K 25-letiju Jurija Dombrovskogo [The Taste of Freedom: Out of the Pages of the Novel. On the 25th Birthday of Jurij Dombrovskij]. Kontinent [The Continent]. 2003. No. 2.

Gej, N. Khudozhestvenij obraz kak kategorija poehtiki [Artistic Image as a Poetics Category]. Kontekst-1982 [Context - 1982]. Moskva: Nauka, 1983.

Gorbacheva, M. Dva Shekspira Ehntoni Berdzhesa [Two Shakespeares of Ant- hony Burgess]. Inostranaja literatura. [Foreign literature]. 2002. No.8.

Gordin, Ja. Vozmozhen li roman o pisateli? [Is a Novel About a Writer Possible?] Voprosy literatury [Literary Issues]. 1975, No. 9.

Leiderman, N. Lipoveckij, M. Sovremennaja ruskaja literatura. 1950-1990-e gody. [Contemporary Russian Literature. 19950-1990.] In 2 volumes. Moskva: Akademija, 2006. Vol. 2, 1968-1990.

Mihalskaja, N. Istorija anglijskoj literatury [History of English literature]. Moskva: Akademija, 2006.

Muravjev V. Berdzhes [Burgess]. Kratkaja literaturnaja ehnciklopedija [Short Literary Encyclopedia]. V. 9, 1978.

Podolskaja I. Dombrovskij [Dombrovskij]. Kratkaja literaturnaja ehnciklopedija [Short Literary Encyclopedia]. V. 9, 1978.

Dombrovskij, Yu. Smuglaja ledi: Roman, povest, novely [Dark Lady: a Novel, a Long Story, Short Stories. Vmesto predislovija Jurija Davydova [In place of Jurij Davydov's preface]. Moskva: Sovetskij pisatel, 1985.

\title{
DU ŠEKSPYRO IૃVAIZDŽIAI ANTHONY BURGESSO ROMANE „NIEKAS NEPRILYGSTA SAULEI“ IR JURIJAUS DOMBROVSKIO APSAKYMUOSE
}

\author{
Nina Bochkareva \\ Permès valstybinis nacionalinis tyrimų universitetas \\ Olga Averkieva \\ Permès kino studija „Novij Kurs“
}

Anotacija. Šio straipsnio tikslas - palyginti Šekspyro ịvaizdžius anglu autoriaus Anthony Burgesso romane "Niekas neprilygsta saulei. Šekspyro meilès gyvenimo istorija“ (1964) ir rusu rašytojo Jurijaus Dombrovskio apsakymuose „Tamsioji dama“, 
"Antroji geroji lova“ ir "Karališkas atsakas“ (1969). Ivaizdžių skirtumai pirmiausia aiškinami skirtingomis literatūrinemis tradicijomis ir realizmo bei modernizmo poetikos bruožais. Panašumai atskleidžia XX a. Europos istoriniu ir literatūriniu procesų bendruosius bruožus bei abiejų autoriu kūrybinių biografiju panašumus, ju bjaurèjimąsi totalitarizmu ir siekị sukurti laisvo asmens ịvaizdị. Užduoties sudètingumas glūdi istorinio asmens įvaizdžio, o ypač Šekspyro įvaizdžio, kūrime. Jis tarsi pridengtas miglos skraiste, per kuriq veikiau įžvelgiame pačiu Burgesso ir Dombrovskio portretus, o ne dramaturgo iš Stratfordo - taip ir liekančio skaitytojui neįminta missle.

Reikšminiai žodžiai: lyginamoji studija, ̨̇vaizdis, žanras, Šekspyras, anglu ir rusų literatūra, Anthony Burgess, Jurij Dombrovskij.

Nina Bochkareva, Permès valstybinis nacionalinis tyrimų universiteto Šiuolaikinių kalbų ir literatūros fakulteto Pasaulio literatūros ir kultūros katedros profesorè. Mokslinių tyrimų sritys: literatūros ir kitų menu sąveika ir sintezé; lyginamoji istorinè romano apie rašytojus analizė, romanas apie kultūrą ir romanas apie romaną Vakarų Europoje, Rusijoje ir JAV.

Nina Bochkareva, Perm State National Research University, Faculty of Modern Foreign Languages and Literatures, Department of World Literature and Culture, Professor. Research interests: investigation of the problems of interaction and synthesis of literature and other arts; comparative historical analysis of the novel about artist, novel about culture and novel about the novel in Western Europe, Russia and the USA

Olga Averkieva, Permès kino studija „Novij Kurs“, režisierè. Tyrimų sritys: literatūros ir kitų menų sąveika ir sintezè.

Olga Averkieva, Perm Film Studio "Novij Kurs”, Director. Research interets: interaction and synthesis of literature and other arts. 